Document downloaded from:

http://hdl.handle.net/10251/147319

This paper must be cited as:

Cordero-Cucart, MT.; Rosado, A.; Majer, E.; Jaramillo Rosales, A.; Rodrigo Tarrega, G.; Daros Arnau, JA. (2018). Boolean Computation in Plants Using Post-translational Genetic Control and a Visual Output Signal. ACS Synthetic Biology. 7(10):2322-2330. https://doi.org/10.1021/acssynbio.8b00214

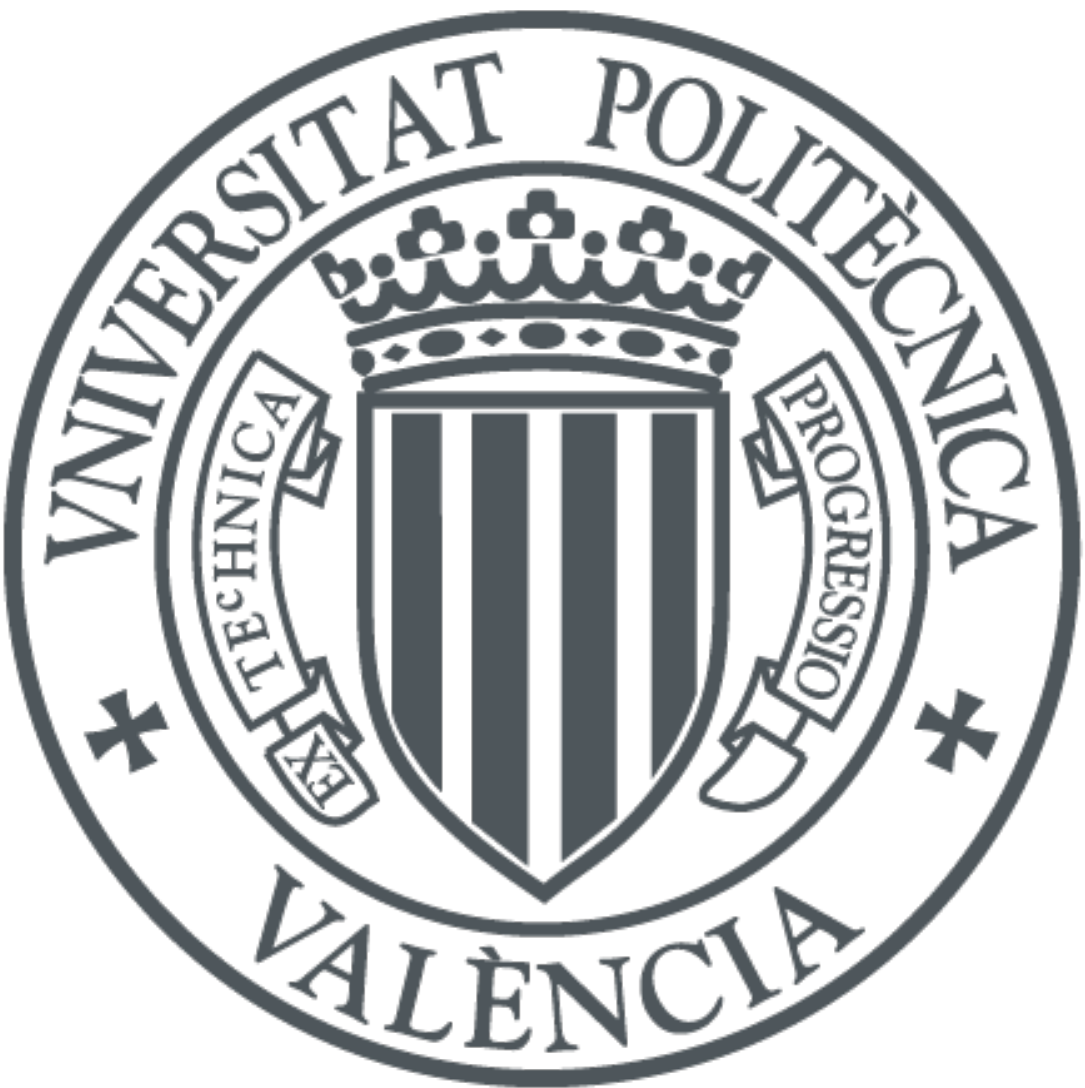

The final publication is available at

https://doi.org/10.1021/acssynbio.8b00214

Copyright American Chemical Society

Additional Information 
Subscriber access provided by Kaohsiung Medical University

Letter

\section{Boolean computation in plants using post- translational genetic control and a visual output signal}

Teresa Cordero, Arantxa Rosado, Eszter Majer, Alfonso Jaramillo, Guillermo Rodrigo, and Jose-Antonio Daros ACS Synth. Biol., Just Accepted Manuscript • DOI: 10.1021/acssynbio.8b00214 • Publication Date (Web): 13 Sep 2018

Downloaded from http://pubs.acs.org on September 14, 2018

\section{Just Accepted}

"Just Accepted" manuscripts have been peer-reviewed and accepted for publication. They are posted online prior to technical editing, formatting for publication and author proofing. The American Chemical Society provides "Just Accepted" as a service to the research community to expedite the dissemination of scientific material as soon as possible after acceptance. "Just Accepted" manuscripts appear in full in PDF format accompanied by an HTML abstract. "Just Accepted" manuscripts have been fully peer reviewed, but should not be considered the official version of record. They are citable by the Digital Object Identifier (DOI®). "Just Accepted" is an optional service offered to authors. Therefore, the "Just Accepted" Web site may not include all articles that will be published in the journal. After a manuscript is technically edited and formatted, it will be removed from the "Just Accepted" Web site and published as an ASAP article. Note that technical editing may introduce minor changes to the manuscript text and/or graphics which could affect content, and all legal disclaimers and ethical guidelines that apply to the journal pertain. ACS cannot be held responsible for errors or consequences arising from the use of information contained in these "Just Accepted" manuscripts. 
1 Boolean computation in plants using post-translational genetic control and 2 a visual output signal

3

4 Teresa Cordero ${ }^{1}$, Arantxa Rosado ${ }^{1,2}$, Eszter Majer ${ }^{1}$, Alfonso Jaramillo ${ }^{2,3,4}$, Guillermo 5 Rodrigo $^{1,2}$, and José-Antonio Daròs*,1

6

$7{ }^{1}$ Instituto de Biología Molecular y Celular de Plantas, CSIC-Universitat Politècnica de 8 València, 46022 Valencia, Spain

$9{ }^{2}$ Institute for Integrative Systems Biology, Universitat de València-CSIC, 46980 Paterna, 10 Spain

$11{ }^{3}$ Warwick Integrative Synthetic Biology Centre and School of Life Sciences, University of 12 Warwick, Coventry, CV4 7AL, UK

13 'Institute of Systems and Synthetic Biology, Université d'Évry Val d'Essonne-CNRS, F91000 Évry, France

ABSTRACT: Due to autotrophic growing capacity and extremely rich secondary metabolism, plants should be preferred targets of synthetic biology. However, developments in plants usually run below those in other taxonomic groups. In this work we engineered genetic circuits able of logic YES, OR and AND Boolean computation in plant tissues with a visual output signal. The circuits, which are deployed by means of Agrobacterium tumefaciens, perform with the conditional activity of the MYB transcription factor Rosea1 from Antirrhinum majus inducing the accumulation of anthocyanins, plant endogenous pigments that are directly visible to the naked eye or accurately quantifiable by spectrophotometric analysis. The translational fusion of Rosea1 to several viral proteins, such as potyvirus NIb or fragments thereof, rendered the transcription factor inactive. However, anthocyanin accumulation could be restored by inserting protease cleavage sites between both moieties of the fusion and by coexpressing specific proteases, such as potyvirus nuclear inclusion a protease.

KEYWORDS: Anthocyanins; Biological computing; Genetic circuits, Potyvirus protease, Synthetic biology 
Plants should be the preferred targets for synthetic biology as they allow the cheap, easy and safe production of many natural compounds of much interest, ${ }^{1}$ due to properties such as autotrophic growing capacity and extremely rich secondary metabolism. ${ }^{2}$ They can also foster the development of novel biosensors ${ }^{3}$ and sustainable interfaces of communication, by exploiting their ability to reshape their physiology and to express heterologous genes. ${ }^{4}$ However, synthetic biology approaches in plants usually run below those in other taxonomic groups, where remarkable examples of logic programs of gene expression exist. ${ }^{5,6}$

The field of synthetic biology has vastly grown in recent years. ${ }^{7}$ Advances have been essentially made on two fronts: foundational and applied synthetic biology. On the one hand, the foundations about the engineering of novel synthetic systems (or the re-engineering of natural ones) have advanced thanks to novel regulatory mechanisms, such as those based on non-coding $\mathrm{RNAs}^{8-10}$ or membrane receptor proteins, ${ }^{11,12}$ fully synthetic functional circuits designed according to rational premises, such as bistables ${ }^{13,14}$ or oscillators, ${ }^{15,16}$ and novel physicochemical models capable of mapping sequence with function. ${ }^{17-19}$ On the other hand, and in parallel to these achievements, some natural systems have been re-engineered to set up new functions in cells to solve applied problems, such as, with plants, the $\beta$-carotene production in rice through metabolic rerouting ${ }^{20}$ or the detection of explosives with a synthetic signal transduction pathway. ${ }^{3}$ To enhance the designability and sophistication of these solutions, more work on the basic mechanisms and circuitries of gene expression control is required. However, we are still quite far from reaching this point in plants, ${ }^{21}$ as most of the aforementioned foundational achievements have been accomplished in bacteria, along with some notable achievements made in yeast and mammalian cells. ${ }^{5}$

The present work aimed to create a regulatory system in plants with the following premises. First, the system would be based on a mechanism of post-translational genetic control, as some previous developments in plants have focused on synthetic transcription regulation, ${ }^{22}$ able to reliably work in different contexts and in a modular fashion. Second, the regulatory mechanism would be specified at the nucleotide level. Third, the output signal would be monitored visually by exploiting the rich secondary metabolism of plants for tissue pigmentation. Then fourth, the genetic system would be encapsulated in agrobacteria to allow the rapid deployment of the engineered circuitry in the plant and avoiding the tedious process of plant stable genetic transformation.

We exploited plant viruses (potyviruses in particular) as a source of genetic material, as pioneers in synthetic biology did with bacteriophages. ${ }^{16}$ Genus Potyvirus comprises the largest group of plus-strand RNA viruses that infect plants. ${ }^{23}$ One of their most distinctive 
properties is their gene expression strategy, which is based on a regulated cascade of proteolytic processing by three virus-encoded proteases to render individual viral proteins from a large polyprotein. ${ }^{23,24} \mathrm{P} 1$ protease and helper-component protease (HC-Pro), the two most amino-terminal products of the viral polyprotein, self-cleave from the precursor, while the rest of proteolytic processing depends on the activity of nuclear inclusion $a$ (NIa) protein, a protease that exquisitely recognizes a seven-amino-acid motif $(-6 /+1)$ that surrounds the different cleavage sites. ${ }^{25}$ The exact amino-acid composition of the various cleavage sites in the viral polyprotein determines the cleavage efficiency, which is the basis of the regulated processing cascade. ${ }^{26} \mathrm{NIa}$ is, in turn, a polyprotein that undergoes self-cleavage at an internal cleavage site that inefficiently splits two domains, VPg and NIaPro, the latter of which is the protease domain itself. Both are multifunctional proteins involved in interactions with a large number of host proteins during infection. ${ }^{27}$ The exact specificity toward the substrate and efficient catalytic activity under broad conditions have converted NIaPro, particularly that from Tobacco etch virus (TEV, genus Potyvirus), into the workhorse of many biotechnological applications. ${ }^{28}$ Here we took advantage of the exquisite specificity of different potyviral NIaPros to implement genetic circuits capable of performing basic logic computations in plants. For the output signal, we considered anthocyanins, plant-endogenous pigments that are readily visible to the naked human eye. ${ }^{29,30}$ In turn, such pigmentation can be accurately quantified in a spectrophotometer by measuring absorbance after simple extraction from plant tissues.

\section{RESULTS AND DISCUSSION}

The master regulator of the anthocyanin pathway is inactive when it is translationally fused to selected proteins or protein fragments. We have previously shown that potyvirus replication and movement through the plant, and those of other viruses that belong to different taxonomic groups, can be visually tracked through the virus-mediated expression of MYB R2R3-type transcription factor Rosea1 from snapdragon (Antirrhinum majus L.). ${ }^{31-35}$ When expressed in plant cells, Roseal activates the production of companion regulatory proteins to form a ternary complex that induces the transcription of anthocyanin biosynthetic genes. ${ }^{29,36}$ Thus, we wondered whether the anthocyanin accumulation induced by Rosea1 activity would also be possible if this transcription factor was translationally fused to a viral protein. This design would be simpler, and consequently more applicable, to different 
101 plant virus families than a design based on the expression of a free protein as viral genomes 102 are highly constrained. ${ }^{37}$

103 To answer this question, we constructed three TEV recombinant clones in which $A$. 104 majus Roseal complementary DNA (cDNA) was fused at the 5' end of P1, HC-Pro, and 105 nuclear inclusion $b$ (NIb, the viral RNA-dependent RNA polymerase) cistrons (TEV-Ros1P1, 106 TEV-Ros1HCPro and TEV-Ros1NIb, respectively, Figure 1A). Figure S1 in Supplementary 107 Information (SI) schematizes these constructs. See the precise nucleotide sequences in SI 108 Figure S2. A few amino acids at the amino termini of HC-Pro and NIb were duplicated to 109 ensure efficient proteolytic processing. Tobacco (Nicotiana tabacum L.) plants were 110 inoculated with the three recombinant TEV clones using Agrobacteriun tumefaciens GV3101 111 to induce systemic virus infection. A TEV-Ros1 clone, in which Roseal cDNA was inserted 112 between cistrons NIb and CP, flanked by artificial NIaPro cleavage sites to release the 113 transcription factor as a free element during polyprotein processing, was used as the positive 114 control (SI Figures S1 and S2). ${ }^{31}$ At 5 days post-inoculation (dpi), all the plants inoculated 115 with TEV-Ros1 started to show infection symptoms. Symptomatic tissues soon (7 dpi) 116 became pigmented in a reddish color, as previously observed. ${ }^{31}$ With the viral clones in which 117 Roseal was translationally fused, infection symptoms also appeared in all the plants 118 inoculated with TEV-Ros1NIb and TEV-Ros1P1, but with some delay (about 10 and 18 dpi, 119 respectively). However, the symptomatic tissues of these plants never appeared to be 120 pigmented (Figure 1B). The plants inoculated with TEV-Ros1HCPro did not show any 121 symptoms after one month of observation. The reverse transcription (RT)-polymerase chain 122 reaction (PCR) amplification of the TEV CP cistron from the RNA preparations from 123 inoculated plants confirmed infection with TEV-Ros1, TEV-Ros1P1 and TEV-Ros1NIb, and 124 also showed asymptomatic infection for TEV-Ros1HCPro (Figure 1C). Tissue samples for 125 this analysis were taken at a late time post-inoculation (30 dpi) to avoid overlooking slow, 126 low titer infections. These results indicate that Roseal is a transcription factor that becomes 127 tightly inactive when translationally fused to some viral proteins, which opens up novel 128 mechanisms for engineering genetic circuits in plants if Rosea1 is able to be released in a 129 controlled manner.

NIaPro can control the activity of Rosea1 at the post-translational level. The observation that Rosea1 becomes inactive when fused to some viral proteins led us to envision a synthetic system in which NIaPro expression would control the activity of Rosea1 at the post-translational level, provided that an appropriate cleavage site is inserted between 
started exploring the Rosea1-NIb fusion because TEV-Ros1NIb was the recombinant virus with the shortest delay in infection. In addition, to avoid any potential interference with TEV NIaPro due to unintended binding - TEV NIa and NIb interact each other ${ }^{38}$, we used a NIb homolog from a phylogenetically distant potyvirus; ${ }^{39}$ i.e. Watermelon mosaic virus (WMV) (Figure 2A). We designed a construct to express a Rosea1-NIb fusion in which the two moieties were separated by a TEV NIaPro cleavage site (Ros1-tev-NIb). We chose the $-8 /+3$ highly efficient cleavage by TEV NIaPro in plants. ${ }^{40}$ The co-expression of the fusion protein and TEV NIaPro in plant tissues were mediated by the Cauliflower mosaic virus (CaMV) $35 \mathrm{~S}$ promoter and terminator, and modified 5' and 3' untranslated regions from Cowpea mosaic virus (CPMV) RNA-2 ${ }^{41}$ (nucleotide sequences in SI Figures S3 and S4). These expression cassettes were inserted between the transfer DNA borders of a binary plasmid for the $A$. tumefaciens-mediated expression in Nicotiana benthamiana Domin. tissues (SI Figure S5). We chose this plant species because of facility in transient expression assays. When the Rosea1-tev-NIb fusion was co-expressed with TEV NIaPro in N. benthamiana leaves, the infiltrated tissue started to turn red at 3 dpi and maintained pigmentation for 2 weeks until the tissue senesced, unlike when the reporter fusion was expressed alone. A picture of a representative leaf at 5 dpi is shown in Figure 2B. From the infiltrated tissues collected at 6 dpi, we extracted anthocyanins and quantified the red pigments at $535 \mathrm{~nm}$ by spectrophotometric measurements, revealing a statistically significant dynamic range in color enrichment (Figure 2C). We set 0.2 in absorbance as the threshold to identify OFF/ON states. These results support the design principle followed herein, and reveal a system that may be used to acquire information from the plant molecular world with the naked eye if NIaPro is placed under the control of a suitable promoter.

Since NIb is a large protein $(59.4 \mathrm{kDa})$, we wondered whether we could delete fragments of it without this affecting the performance of the regulatory system. We prepared several versions of the Ros1-tev-NIb construct with successive deletions of the NIb moiety from the carboxyl terminus (Figure 3A, nucleotide sequences in SI Figure S3). Then we assayed anthocyanin accumulation in $N$. benthamiana leaves by co-expressing these constructs with TEV NIaPro (Figure 3B). The NIb deleted forms that consisted of the 300, 200, and 100 amino-terminal amino acids of the polymerase prevented Rosea1 activity, which was efficiently restored upon the co-expression of TEV NIaPro. In contrast, the deleted forms that consisted of the 50 and 25 amino-terminal amino acids of NIb were not sufficient to 
168

169

170

171

172

173

174

175

176

177

178

179

180

181

182

183

184

185

186

187

188

189

190

191

192

193

194

195

196

197

198

199

200

201

inhibit Roseal activity (Figure 3C). In view of these results, we chose the 100 aminoterminal amino acids of WMV NIb $\left(\mathrm{NIb}_{100}\right)$ to conduct further work.

Next, we explored the possibility of using proteases from other potyviruses, expanding this way the available elements for genetic engineering. To this end, we made two parallel constructs: one to express Tobacco vein mottle virus (TVMV, genus Potyvirus) NIaPro, a homologous protease that recognizes a different cleavage motif; ${ }^{42}$ another to express a modified version of the reporter in which the $-8 /+3$ TEV NIaPro cleavage site was replaced with the corresponding site associated with TVMV NIaPro (Ros1-tvmv-NIb ${ }_{100}$; Figure 3D; nucleotide sequences in SI Figures S3 and S4). Once again, we chose the amino acids surrounding the $\mathrm{NIb} / \mathrm{CP}$ cleavage site in this new virus. This system was also significantly responsive (statistically) to the expression of that NIaPro, although with lower dynamic range in color enrichment (TEV NIaPro led to absorbance $\sim 1$, while TVMV NIaPro to $\sim 0.5$ ). Note the different scales of the y axis in Figure 3D. We also found that the two proteases did not show cross-reactivity (with statistical significance) in the co-expression experiments of the non-cognate pairs (Figure 3D).

Genetic circuits able of basic Boolean computation in plants with a visual output signal. Finally, we investigated whether this regulatory strategy would be amenable for basic Boolean computation in plants. We focused on two-input logic gates using TEV and TVMV NIaPros. On the one hand, we aimed at engineering an OR logic gate. To this end, we designed a new system in which the cDNA of the transcription factor was separated from the cDNA of the NIb-derived inhibitory fragment by two contiguous protease-cleaving domains (Ros1-tvmv-tev-NIb ${ }_{100}$; Figure 4A, nucleotide sequence in SI Figure S3); one corresponded to TVMV NIaPro and the other to TEV NIaPro. In this way, each protease could independently release the transcription factor. When assayed in plants, we found that both proteases indeed produced tissue pigmentation (Figure 4B). However, we noticed asymmetric color enrichment, expected by the fact that TEV NIaPro is more efficient than TVMV NIaPro. In addition, while TEV protease indeed led to a statistically significant dynamic range, the boost induced by TVMV protease was marginally non-significant, despite the mean absorbance was above 0.2 . In this regard, our system would be benefited by the development of new proteases with enhanced activity.

On the other hand, we aimed at engineering an AND logic gate. In order to do this, we flanked the Rosea1 cDNA, both upstream and downstream, by two NIb-derived inhibitory fragments, each of which was separated by three copies of specific NIaPro cleavage sites $\left(\mathrm{NIb}_{100}-3 \times t e v-\mathrm{Ros} 1-3 \times t v m v-\mathrm{NIb}_{100}\right.$; Figure 5A; SI Figure S3). Three copies of the cleavage 
202 sites were used to increase the efficiency of Roseal release. We had previously assayed a 203 construct that only had one site per flank $\left(\mathrm{NIb}_{100}-t e v\right.$-Ros1-tvmv-NIb$\left.{ }_{100}\right)$, obtaining unsatisfactory results. Accordingly, we expected the transcription factor to be released only in presence of the two proteases. The co-expression of this new reporter construct with either TEV or TVMV NIaPros did not produce statistically significant anthocyanin accumulation, and even the mean absorbance was below the threshold set. However, the co-expression with both proteases (SI Figure S4) at the same time produced statistically significant color enrichment (Figure 5B). In this case of cooperation, the dynamic range was limited by the protease with lower activity (TVMV NIaPro).

Perspectives on synthetic genetic circuits deployed in plant tissues through agrobacteria. The results herein show that increasingly sophisticated gene expression programs can be implemented into plants by gathering distinct genetic elements with reliable properties; in this case, sequence-specific viral proteases (potyviral NIaPros) and a metabolic regulator (transcription factor Rosea1). Notably, circuits that exploit these proteases have been recently developed in bacteria. ${ }^{43,44}$ The successful engineering (rational design, genetic implementation and accurate characterization) of synthetic circuitries that lead to such programs promises the engineering of novel organisms with improved or added functionalities that would be profitable in biotechnological or biomedical applications with increasing sophistication. ${ }^{45}$ Our aim in this work was to deploy the synthetic circuits in plant tissues using the natural gene transfer capabilities of $A$. tumefaciens. ${ }^{46}$ In contrast to the timeconsuming process of plant transformation, A. tumefaciens can be rapid and efficiently transformed. In addition, once an engineered A. tumefaciens clone is constructed, the synthetic elements it bears can be expressed alone or in combination with other elements expressed by the plant or different $A$. tumefaciens clones in a week time scale and in a limited portion of the plant.

This work represents, in our view, a step toward the engineering of logic circuits in plants, ${ }^{21}$ where the different logic gates that we created herein will provide the building blocks to rationally construct larger circuits. As we implemented the Boolean operations through irreversible post-translational events, transcriptional regulation remains to couple these logic gates with environmental or cellular signals. The relevance of our development is in the use of a visual output signal, which opens the door to test synthetic biology prototypes in the field. Broadly speaking, as our ability to engineer the conditional accumulation of pigments in plant tissues increases, following the processing of different inputs through complex genetic circuits, novel information transmission systems between plants and humans 
236 (or machines) are expected to arise, especially in a global scenario of search for sustainable 237 elements. This is not otherwise different, at least in concept, from the plant-animal communication channels already observed in nature. ${ }^{47} \mathrm{We}$ envision the use of ready-to-use portable genetic systems encapsulated in agrobacteria to be used as smart biodevices that can make appropriate decisions (e.g., in diagnostics) after certain processing (computation) of the signals perceived from the plant molecular medium. ${ }^{48}$

\section{MATERIALS AND METHODS}

Plasmid construction. Plasmids were constructed by Gibson assembly, ${ }^{49}$ using the NEBuilder HiFi DNA Assembly master mix (New England Biolabs). For this purpose, DNA fragments were amplified by PCR using the Phusion High-Fidelity DNA polymerase (Thermo Scientific). The sequences of the resulting constructs (SI Figures S2, S3 and S4) were experimentally confirmed (3130xl Genetic Analyzer, Life Technologies). The plasmids to express TEV recombinant clones TEV-Ros1, TEV-Ros1P1, TEV-Ros1HCPro and TEVRos1NIb (SI Figure S2) were constructed on the basis of pGTEVa. ${ }^{33}$ The plasmids to express reporter constructs Ros1-tev-NIb (and the deleted versions with $\mathrm{NIb}_{300}, \mathrm{NIb}_{200}, \mathrm{NIb}_{100}, \mathrm{NIb}_{50}$

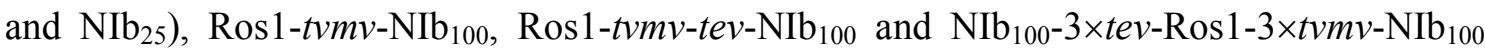
(SI Figure S3), as well as the plasmids to singly express and co-express the TEV and TVMV NIaPros (SI Figure S4), were constructed on the basis of pG35CPMVZ (SI Figure S5). This plasmid is a derivative of pCLEAN-G181 (GenBank accession number EU186083) and pG35Z, ${ }^{34}$ which contains, between the left and right borders of T-DNA, an expression cassette that consist of the CaMV 35S promoter, a modified version of the CPMV RNA-2 5' UTR, ${ }^{50}$ a polylinker with two Bsa I sites, CPMV RNA-2 3' UTR, and the CaMV 35S terminator.

Plant inoculation for viral infection. A. tumefaciens GV3101:pMP90, which contained helper plasmid pCLEAN-S48, ${ }^{51}$ were transformed with the different plasmids that contained the recombinant TEV clones with Rosea1 cDNA in various positions (Fig. S1). The transformed $A$. tumefaciens were grown to an optical density at $600 \mathrm{~nm}\left(\mathrm{OD}_{600}\right)$ of approximately 1.0 and recovered by centrifugation. Cells were resuspended at an $\mathrm{OD}_{600}$ of 0.5 in $10 \mathrm{mM}$ MES-NaOH, pH 5.6, $10 \mathrm{mM} \mathrm{MgCl}_{2}$ and $150 \mu \mathrm{M}$ acetosyringone, and induced for 3 $\mathrm{h}$ at $28^{\circ} \mathrm{C}$. These cultures were used to agroinoculate the 4.5 -week-old tobacco (Nicotiana tabacum L. cv. Xanthi nc) plants that were cultivated in a growth chamber at $25^{\circ} \mathrm{C}$ in a $12-\mathrm{h}$ day-night photoperiod. 
Analysis of viral infection by RT-PCR. RNA was purified from the upper noninoculated leaves of the inoculated tobacco plants using silica gel columns (Zymo Research). Aliquots of the RNA preparations were subjected to reverse transcription with primer P1 (5'CTCGCACTACATAGGAGAATTAGAC-3'). The products of this reaction were amplified by PCR with Thermus thermophilus DNA polymerase (Biotools) using a pair of primers (PII 5'-AGTGGCACTGTGGGTGCTGGTGTTG-3' and PIII 5'-CTGGCGGACCCCTAATAG3'), respectively homologous and complementary to the 5' and 3' ends of TEV coat protein cistron. The PCR products were separated by electrophoresis in a $1 \%$ agarose gel in TAE buffer (40 mM Tris, $20 \mathrm{mM}$ sodium acetate, $1 \mathrm{mM}$ EDTA, $\mathrm{pH}$ 7.2). The gel was finally stained in a solution of $1 \mathrm{mg} / \mathrm{ml}$ ethidium bromide.

Plant inoculation for transient expression of synthetic circuits. A. tumefaciens (the same strain as above) were also transformed with plasmids to express the reporter constructs (SI Figure S3) and TEV and TVMV NIaPros (SI Figure S4). Cultures were grown, harvested and induced as explained above with the only difference being that here induction was done at an $\mathrm{OD}_{600}$ of 1.0. In the different experiments, the A. tumefaciens cultures that expressed the reporter constructs were mixed with an equal volume of agroinoculation buffer (controls) or with the cultures that expressed the different NIaPro combinations. These mixtures were used to infiltrate the underside of leaves from the 4.5-week-old $N$. benthamiana plants using a needleless syringe. Plants were cultivated as explained above.

Analysis of anthocyanins. The infiltrated tissues from the $N$. benthamiana plants were harvested at $6 \mathrm{dpi}$ and homogenized in 10 volumes of extraction solution $(1 \% \mathrm{HCl}$ in methanol) with a Polytron (Kinematica). Each individual tissue sample consisted of two agroinfiltrated areas from two different leaves of the same plant. Extracts were vigorously vortexed and incubated on ice for $1 \mathrm{~h}$ with sporadic vortexing. Extracts were clarified by centrifugation for $10 \mathrm{~min}$ at $12000 \mathrm{~g}$. The aliquots of the supernatants were diluted to 1:10 in extraction solution (final tissue:extraction solution ratio of 1:100) and absorbance was measured at $535 \mathrm{~nm}$ (UV-3100PC, VWR). All the experimental values were obtained in triplicate from the agroinfiltrated tissues from three independent plants. The average $(n=5)$ absorbance of control extracts from tissues infiltrated under the same conditions with an empty A. tumefaciens culture (no expression plasmid) were subtracted from all absorbance values (to remove the basal contribution from the plant). Background absorbance was 0.148 and 0.149 , respectively, for samples corresponding to final $\mathrm{OD}_{600}$ of 0.5 and 1.0 .

\section{ASSOCIATED CONTENT}


303

304

305

306

307

308

309

310

311

312

313

314

315

316

317

318

319

320

321

322

323

324

325

326

327

328

329

330

331

332

333

334

335

\section{Supporting Information}

The Supporting Information is available free of charge on the ACS Publications website.

Additional figures as described in the text (PDF).

Figure S1. Schematic representation of TEV genome indicating the positions where the Rosea1 coding sequence was fused in TEV-Ros1P1, TEV-Ros1HCPro and TEV-Ros1NIb.

Figure S2. Sequences of recombinant TEV clones.

Figure S3. Sequences of the synthetic reporter constructs that allow Boolean computation in plant tissues with visual output.

Figure S4. Sequences of the constructs to singly express TEV and TVMV NIaPros and to coexpress both proteases in plant tissues.

Figure S5. Sequence of expression vector pG53CPMVZ used to express in plant tissues the synthetic reporter constructs, as well as the potyviral NIaPros.

\section{AUTHOR INFORMATION}

\section{Corresponding Author}

*E-mail: jadaros@ibmcp.upv.es

\section{ORCID}

José-Antonio Daròs: 0000-0002-6535-2889

\section{Author Contributions}

J.-A.D., G.R. and A.F. conceived the work with inputs from all other authors. T.C., A.R. and E.M. performed the experiments. All authors analyzed the data. J.-A.D. and G.R. wrote the manuscript with inputs from all the other authors.

Notes

The authors declare no competing financial interest.

\section{ACKNOWLEDGEMENTS}


336 This research was supported by the Ministerio de Ciencia, Innovación y Universidades 337 (Spain) grants AGL2013-49919-EXP, BIO2014-54269-R, BFU2015-66894-P and BIO2017338 83184-R (co-financed FEDER funds) and by the Engineering and Physical Sciences Research 339 Council and the Biotechnology and Biological Sciences Research Council (UK) grant 340 BB/M017982/1. E.M. was the recipient of a pre-doctoral fellowship (AP2012-3751) from the 341 Ministerio de Educación, Cultura y Deporte (Spain).

342

\section{REFERENCES}

(1) Phoolcharoen, W., Bhoo, S. H., Lai, H., Ma, J., Arntzen, C. J., Chen, Q., and Mason, H. S. (2011) Expression of an immunogenic Ebola immune complex in Nicotiana benthamiana. Plant Biotechnol. J. 9, 807-816.

(2) Verpoorte, R., and Memelink, J. (2002) Engineering secondary metabolite production in plants. Curr. Opin. Biotechnol. 13, 181-187.

(3) Antunes, M. S., Morey, K. J., Smith, J. J., Albrecht, K. D., Bowen, T. A., Zdunek, J. pathway. PLoS One 6, e16292.

(4) Desai, P. N., Shrivastava, N., and Padh, H. (2010) Production of heterologous proteins in plants: strategies for optimal expression. Biotechnol. Adv. 28, 427-435.

(5) Ausländer, S., Ausländer, D., Muller, M., Wieland, M., and Fussenegger, M. (2012) Programmable single-cell mammalian biocomputers. Nature 487, 123-127.

(6) Siuti, P., Yazbek, J., and Lu, T. K. (2013) Synthetic circuits integrating logic and memory in living cells. Nat. Biotechnol. 31, 448-452.

(7) Cameron, D. E., Bashor, C. J., and Collins, J. J. (2014) A brief history of synthetic biology. Nat. Rev. Microbiol. 12, 381-390.

(8) Win, M. N., and Smolke, C. D. (2007) A modular and extensible RNA-based generegulatory platform for engineering cellular function. Proc. Natl. Acad. Sci. USA 104, 1428314288.

(9) Qi, L. S., Larson, M. H., Gilbert, L. A., Doudna, J. A., Weissman, J. S., Arkin, A. P., and Lim, W. A. (2013) Repurposing CRISPR as an RNA-guided platform for sequencespecific control of gene expression. Cell 152, 1173-1183.

(10)Chappell, J., Takahashi, M. K., and Lucks, J. B. (2015) Creating small transcription activating RNAs. Nat. Chem. Biol. 11, 214-220. 
(11)Dueber, J. E., Mirsky, E. A., and Lim, W. A. (2007) Engineering synthetic signaling proteins with ultrasensitive input/output control. Nat. Biotechnol. 25, 660-662.

(12)Levskaya, A., Chevalier, A. A., Tabor, J. J., Simpson, Z. B., Lavery, L. A., Levy, M., Davidson, E. A., Scouras, A., Ellington, A. D., Marcotte, E. M., and Voigt, C. A. (2005) Synthetic biology: engineering Escherichia coli to see light. Nature 438, 441-442.

(13) Gardner, T. S., Cantor, C. R., and Collins, J. J. (2000) Construction of a genetic toggle switch in Escherichia coli. Nature 403, 339-342.

(14)Friedland, A. E., Lu, T. K., Wang, X., Shi, D., Church, G., and Collins, J. J. (2009) Synthetic gene networks that count. Science 324, 1199-1202.

(15) Stricker, J., Cookson, S., Bennett, M. R., Mather, W. H., Tsimring, L. S., and Hasty, J. (2008) A fast, robust and tunable synthetic gene oscillator. Nature 456, 516-519.

(16)Elowitz, M. B., and Leibler, S. (2000) A synthetic oscillatory network of transcriptional regulators. Nature 403, 335-338.

(17) Salis, H. M., Mirsky, E. A., and Voigt, C. A. (2009) Automated design of synthetic ribosome binding sites to control protein expression. Nat. Biotechnol. 27, 946-950.

(18) Mutalik, V. K., Qi, L., Guimaraes, J. C., Lucks, J. B., and Arkin, A. P. (2012) Rationally designed families of orthogonal RNA regulators of translation. Nat. Chem. Biol. 8 , 447-454.

(19)Kinney, J. B., Murugan, A., Callan, C. G., Jr., and Cox, E. C. (2010) Using deep sequencing to characterize the biophysical mechanism of a transcriptional regulatory sequence. Proc. Natl. Acad. Sci. USA 107, 9158-9163.

(20)Ye, X., Al-Babili, S., Klöti, A., Zhang, J., Lucca, P., Beyer, P., and Potrykus, I. (2000) Engineering the provitamin A ( $\beta$-carotene) biosynthetic pathway into (carotenoid-free) rice endosperm. Science 287, 303-305.

(21) de Lange, O., Klavins, E., and Nemhauser, J. (2017) Synthetic genetic circuits in crop plants. Curr. Opin. Biotechnol. 49, 16-22.

(22) Schaumberg, K. A., Antunes, M. S., Kassaw, T. K., Xu, W., Zalewski, C. S., Medford, J. I., and Prasad, A. (2016) Quantitative characterization of genetic parts and circuits for plant synthetic biology. Nat. Methods 13, 94-100.

(23)Revers, F., and García, J. A. (2015) Molecular biology of potyviruses. Adv. Virus Res. 92, 101-199.

(24) Verchot, J., Koonin, E. V., and Carrington, J. C. (1991) The 35-kDa protein from the $\mathrm{N}$-terminus of the potyviral polyprotein functions as a third virus-encoded proteinase. Virology 185, 527-535. 
404

405

406

407

408

409

410

411

412

413

414

415

416

417

418

419

420

421

422

423

424

425

426

427

428

429

430

431

432

433

434

435

(25) Adams, M. J., Antoniw, J. F., and Beaudoin, F. (2005) Overview and analysis of the polyprotein cleavage sites in the family Potyviridae. Mol. Plant Pathol. 6, 471-487.

(26) Carrington, J. C., and Dougherty, W. G. (1987) Small nuclear inclusion protein encoded by a plant potyvirus genome is a protease. J. Virol. 61, 2540-2548.

(27)Martínez, F., Rodrigo, G., Aragonés, V., Ruiz, M., Lodewijk, I., Fernández, U., Elena, S. F., and Daròs, J. A. (2016) Interaction network of tobacco etch potyvirus NIa protein with the host proteome during infection. BMC Genomics 17, 87.

(28)Cesaratto, F., Burrone, O. R., and Petris, G. (2016) Tobacco Etch Virus protease: A shortcut across biotechnologies. J. Biotechnol. 231, 239-249.

(29)Zhang, Y., Butelli, E., and Martin, C. (2014) Engineering anthocyanin biosynthesis in plants. Curr. Opin. Plant Biol. 19, 81-90.

(30)Butelli, E., Titta, L., Giorgio, M., Mock, H. P., Matros, A., Peterek, S., Schijlen, E. G., Hall, R. D., Bovy, A. G., Luo, J., and Martin, C. (2008) Enrichment of tomato fruit with health-promoting anthocyanins by expression of select transcription factors. Nat. Biotechnol. 26, 1301-1308.

(31)Bedoya, L. C., Martínez, F., Orzáez, D., and Daròs, J. A. (2012) Visual tracking of plant virus infection and movement using a reporter MYB transcription factor that activates anthocyanin biosynthesis. Plant Physiol. 158, 1130-1138.

(32) Majer, E., Llorente, B., Rodríguez-Concepción, M., and Daròs, J. A. (2017) Rewiring carotenoid biosynthesis in plants using a viral vector. Sci. Rep. 7, 41645.

(33) Majer, E., Daròs, J. A., and Zwart, M. P. (2013) Stability and fitness impact of the visually discernible Rosea1 marker in the Tobacco etch virus genome. Viruses 5, 2153-2168.

(34)Cordero, T., Cerdán, L., Carbonell, A., Katsarou, K., Kalantidis, K., and Daròs, J. A. (2017) Dicer-Like 4 Is Involved in Restricting the Systemic Movement of Zucchini yellow mosaic virus in Nicotiana benthamiana. Mol. Plant Microbe Interact. 30, 63-71.

(35)Cordero, T., Mohamed, M. A., López-Moya, J. J., and Daròs, J. A. (2017) A recombinant Potato virus $Y$ infectious clone tagged with the Roseal visual marker (PVYRos1) facilitates the analysis of viral infectivity and allows the production of large amounts of anthocyanins in Plants. Front. Microbiol. 8, 611.

(36) Passeri, V., Koes, R., and Quattrocchio, F. M. (2016) New challenges for the design of high value plant products: stabilization of anthocyanins in plant vacuoles. Front. Plant Sci. 7, 153. 
436

437

438

439

440

441

442

443

444

445

446

447

448

449

450

451

452

453

454

455

456

457

458

459

460

461

462

463

464

465

466

467

468

(37) Majer, E., Salvador, Z., Zwart, M. P., Willemsen, A., Elena, S. F., and Daròs, J. A. (2014) Relocation of the NIb gene in the tobacco etch potyvirus genome. J. Virol. 88, 45864590 .

(38)Li, X. H., Valdez, P., Olvera, R. E., and Carrington, J. C. (1997) Functions of the tobacco etch virus RNA polymerase $(\mathrm{NIb})$ : subcellular transport and protein-protein interaction with VPg/proteinase (NIa). J. Virol. 71, 1598-1607.

(39) Gibbs, A., and Ohshima, K. (2010) Potyviruses and the digital revolution, Annu. Rev. Phytopathol. 48, 205-223.

(40)Bedoya, L., Martínez, F., Rubio, L., and Daròs, J. A. (2010) Simultaneous equimolar expression of multiple proteins in plants from a disarmed potyvirus vector. J. Biotechnol. 150, 268-275.

(41) Sainsbury, F., Thuenemann, E. C., and Lomonossoff, G. P. (2009) pEAQ: versatile expression vectors for easy and quick transient expression of heterologous proteins in plants. Plant Biotechnol. J. 7, 682-693.

(42)Tözsér, J., Tropea, J. E., Cherry, S., Bagossi, P., Copeland, T. D., Wlodawer, A., and Waugh, D. S. (2005) Comparison of the substrate specificity of two potyvirus proteases. FEBS J. 272, 514-523.

(43)Calles, B., and de Lorenzo, V. (2013) Expanding the boolean logic of the prokaryotic transcription factor XylR by functionalization of permissive sites with a protease-target sequence. ACS Synth. Biol. 2, 594-603.

(44)Fernandez-Rodriguez, J., and Voigt, C. A. (2016) Post-translational control of genetic circuits using Potyvirus proteases. Nucleic Acids Res. 44, 6493-6502.

(45)Khalil, A. S., and Collins, J. J. (2010) Synthetic biology: applications come of age. Nat. Rev. Genet. 11, 367-379.

(46) Sainsbury, F., and Lomonossoff, G. P. (2014) Transient expressions of synthetic biology in plants. Curr. Opin. Plant Biol. 19, 1-7.

(47) Schaefer, H. M., Schaefer, V., and Levey, D. J. (2004) How plant-animal interactions signal new insights in communication. Trends Ecol. Evol. 19, 577-584.

(48)Riglar, D. T., and Silver, P. A. (2018) Engineering bacteria for diagnostic and therapeutic applications. Nat. Rev. Microbiol. 16, 214-225.

(49)Gibson, D. G., Young, L., Chuang, R. Y., Venter, J. C., Hutchison, C. A., 3rd, and Smith, H. O. (2009) Enzymatic assembly of DNA molecules up to several hundred kilobases. Nat. Methods 6, 343-345. 


\begin{abstract}
469 (50) Sainsbury, F., and Lomonossoff, G. P. (2008) Extremely high-level and rapid transient 470 protein production in plants without the use of viral replication. Plant. Physiol. 148, $1212-$ 4711218.

472 (51)Thole, V., Worland, B., Snape, J. W., and Vain, P. (2007) The pCLEAN dual binary 473 vector system for Agrobacterium-mediated plant transformation. Plant Physiol. 145, 1211$474 \quad 1219$.
\end{abstract}

475

476 
Figures

A
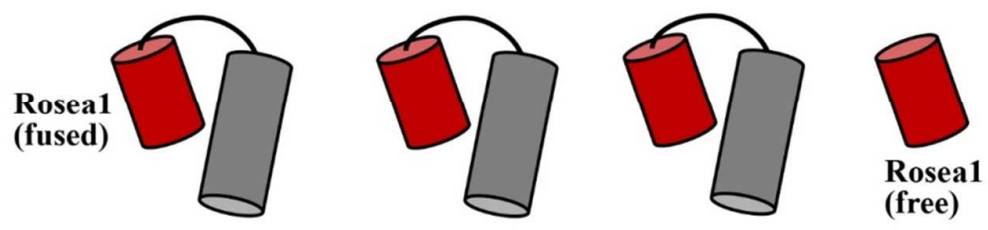

TEV P1

TEV HCPro

TEV NIb
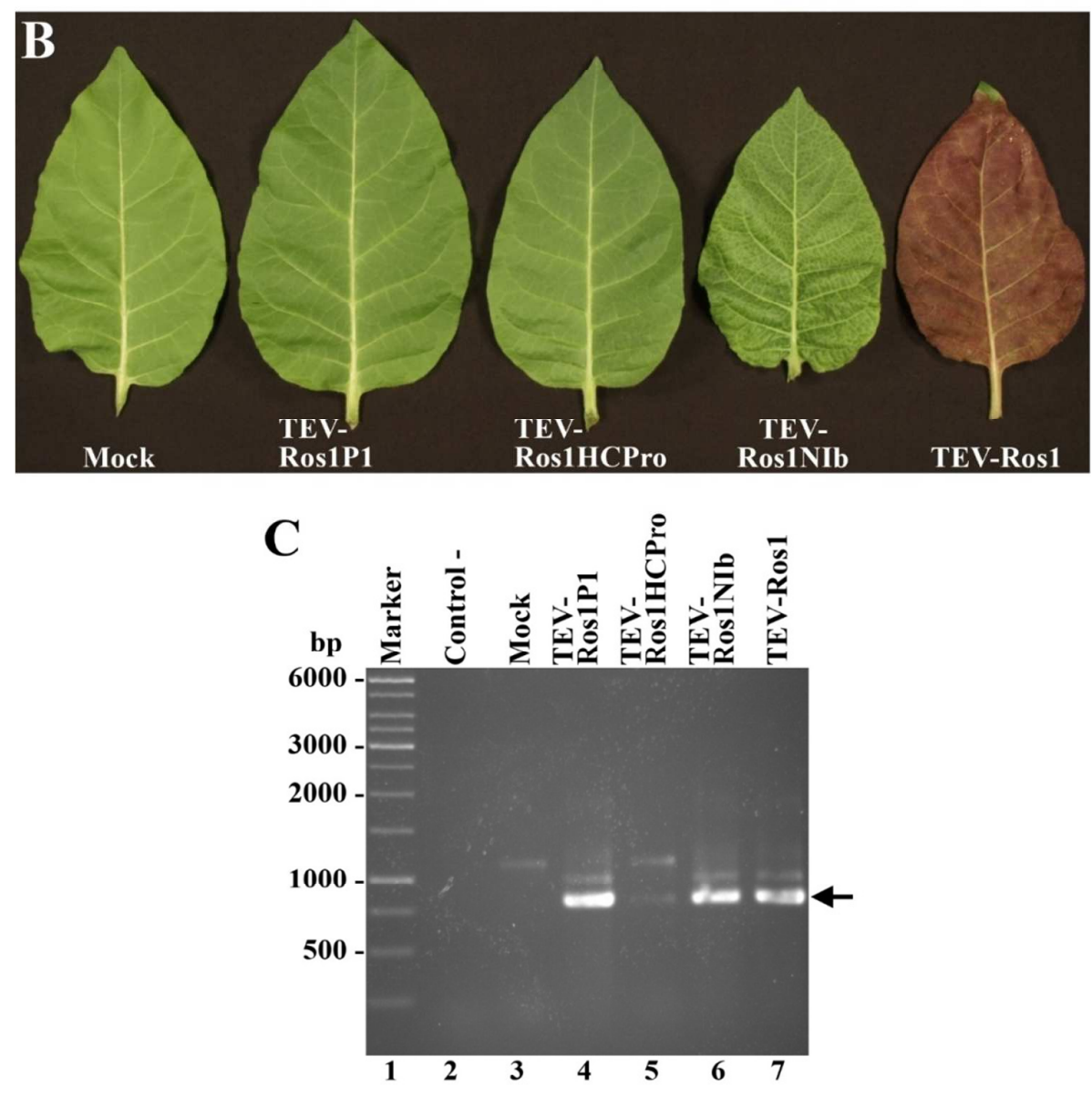

479

480

481

482

483

484

485

486

487

488

489

490

Figure. 1. Plant inoculation with TEV recombinant clones in which the Roseal transcription factor was fused to different viral proteins. (A) Schematic representation of the different Rosea1 fusions. (B) Representative systemic leaves of tobacco plants mock-inoculated or inoculated with TEV-Ros1P1, TEV-Ros1HCPro, TEV-Ros1NIb and TEV-Ros1, as indicated. Pictures were taken at 11 dpi. (C) RT-PCR TEV diagnosis of systemic tissue from tobacco plants inoculated with recombinant TEV clones. PCR products were separated by electrophoresis in an agarose gel that was stained with ethidium bromide. Lane 0, DNA marker ladder with the size of some molecules on the left in bp; lane 1, RT-PCR negative control with no added RNA; lanes 3 to 7, RT-PCR products from systemic tissues of plants mock-inoculated and inoculated with TEV-Ros1P1, TEV-Ros1HCPro, TEV-Ros1NIb and TEV-Ros1, respectively. The arrow points out the expected band in infected tissues that corresponds to TEV coat protein cDNA. 
2

3

4

5

6

7

8
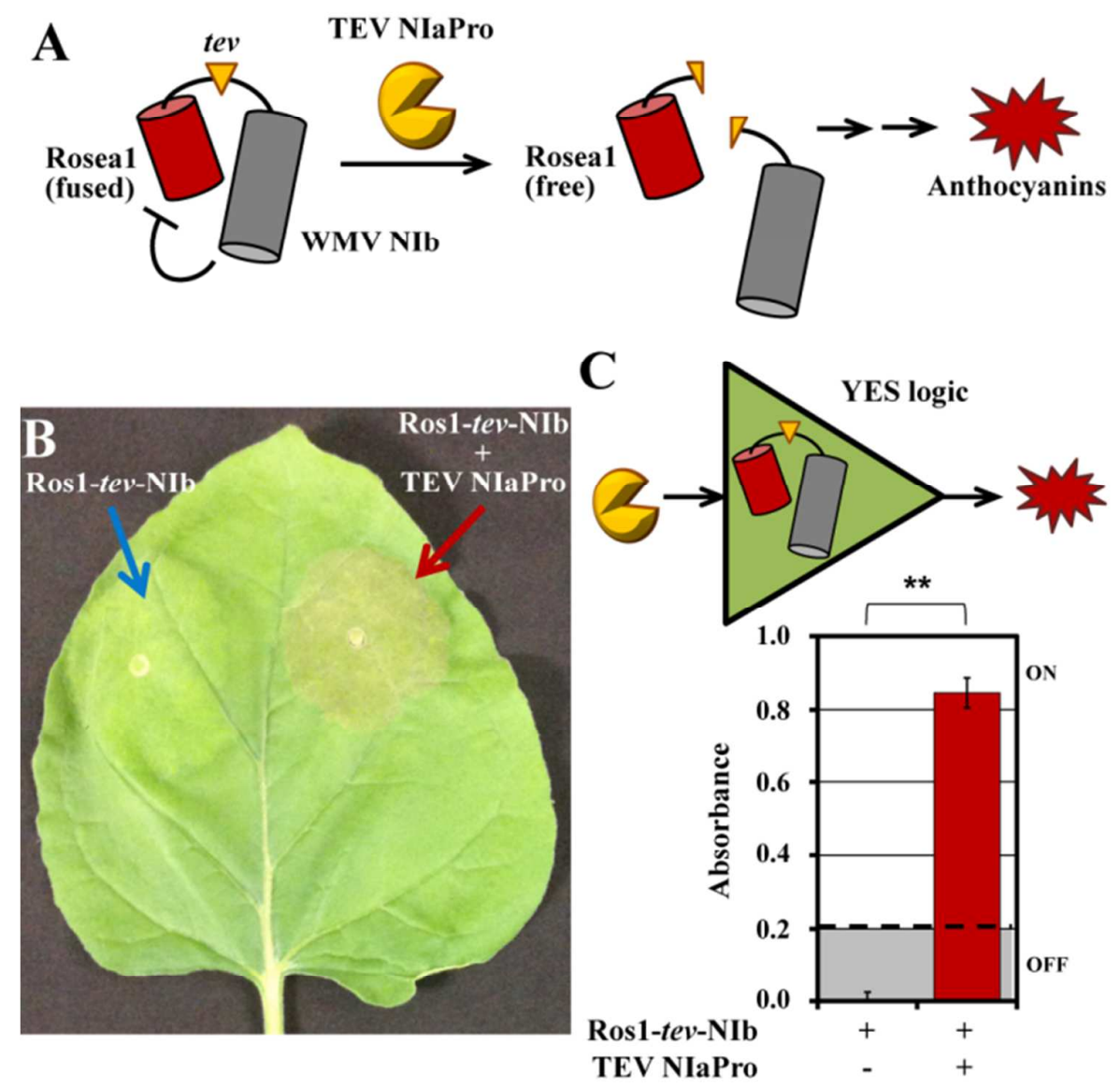

491

Figure 2. NIaPro-based proteolytic activation of Rosea1. (A) Schematic representation of the proteolytic reaction in which TEV NIaPro cleaves the inactive fusion reporter construct Ros1tev-NIb releasing the Roseal transcription factor that activates pigmented anthocyanin biosynthesis. (B) Representative picture of an $N$. benthamiana leaf infiltrated with $A$. tumefaciens to express the NIb-tev-Ros1 reporter (left) or the reporter plus TEV NIaPro (right). Picture was taken at $5 \mathrm{dpi}$. (C) Graphic representation of the absorbance in $N$. benthamiana tissues infiltrated with $A$. tumefaciens to express the NIb-tev-Ros1 reporter alone or with TEV NIaPro. Tissues from three independent plants were collected at 6 dpi, anthocyanins were extracted and the absorbance at $535 \mathrm{~nm}$ was measured. Error bars represent the standard error of the mean. ${ }^{* *} P \leq 0.01$ (one-tailed, heteroscedastic $t$-test). 
A

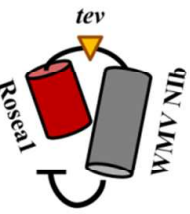

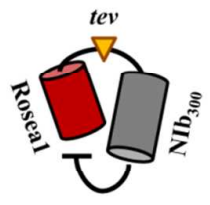
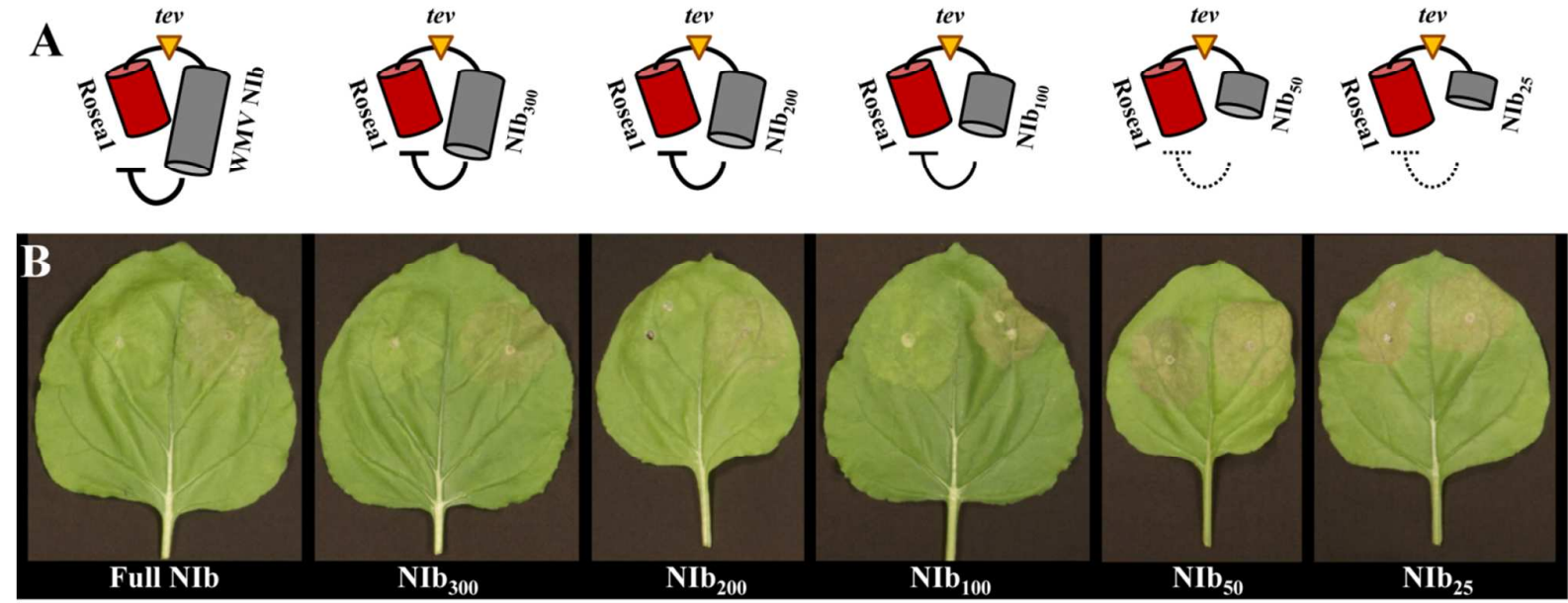

C

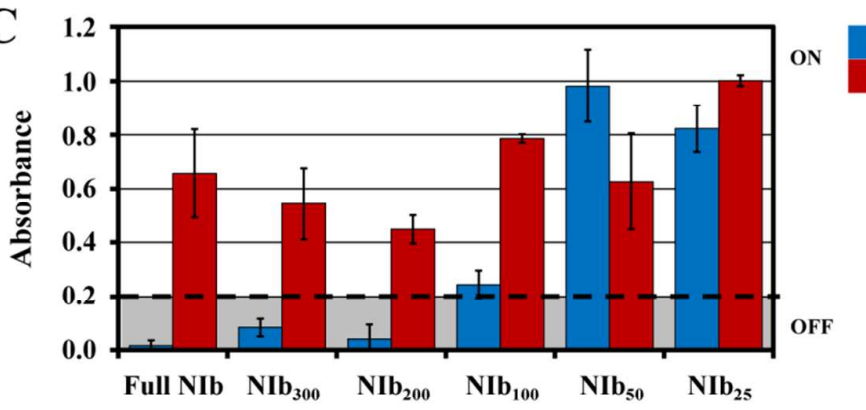

D
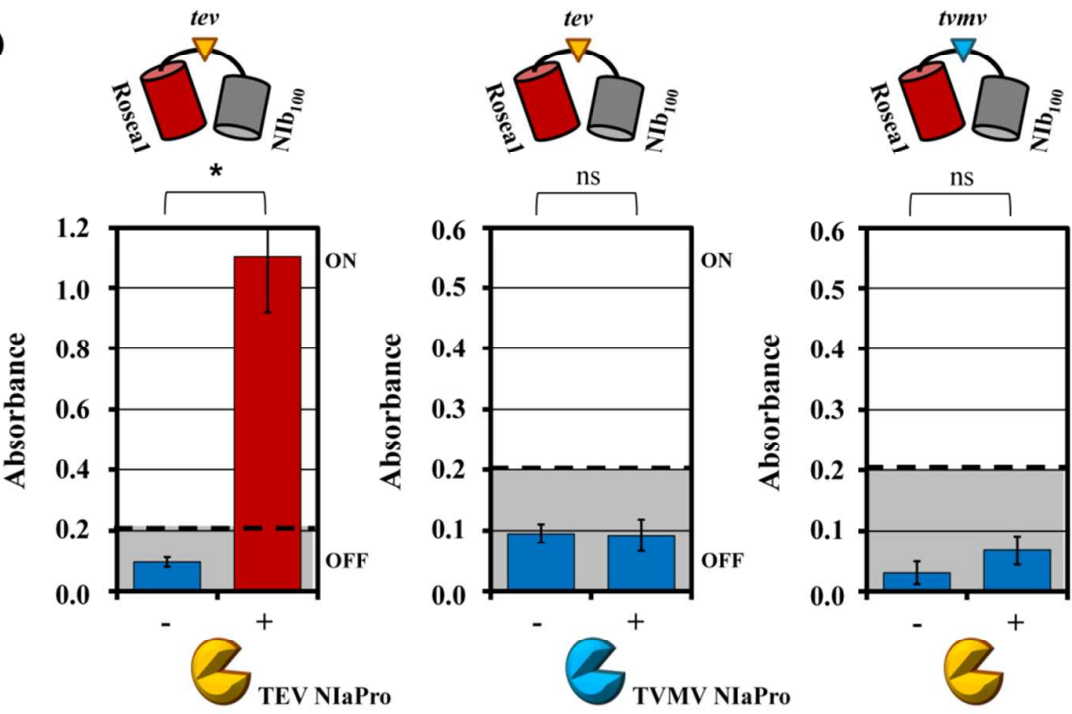
- TEV NIaPro
+ TEV NIaPro

Figure 3. Inhibition of Roseal activity by WMV NIb fragments. (A) Schematic representation of the different Ros1-tev-NIb reporter constructs with increasing NIb deletions. $\mathrm{NIb}$ subscript indicates the remaining amino terminal amino acids in the WMV NIb deleted forms. (B) Representative pictures of $N$. benthamiana leaves infiltrated with $A$. tumefaciens to express different forms of the Ros1-tev-NIb reporter with the full WMV NIb or amino terminal fragments, as indicated in number of amino acids. On each leaf, the reporter was infiltrated alone on the left and with TEV NIaPro on the right. Pictures were taken at 5 dpi. (C) Graphic representation of the absorbance in $N$. benthamiana tissues infiltrated with $A$. tumefaciens to express the different Ros1-tev-NIb reporters, as indicated, either alone (blue 
511 bars) or with TEV NIaPro (red bars). (D) Graphic representation of the absorbance in $N$. 512 benthamiana tissues infiltrated with A. tumefaciens to express the Ros1-tev-NIb or Ros1$513 t v m v-\mathrm{NIb}$ reporters, as indicated, either alone (blue bars) or with TEV NIaPro or TVMV 514 NIaPro, as indicated (red bars). (C and D) Tissues from three independent plants were 515 collected at $6 \mathrm{dpi}$, anthocyanins were extracted and the absorbance at $535 \mathrm{~nm}$ was measured. 516 Error bars represent the standard error of the mean. (D) ${ }^{*} P \leq 0.05$ (one-tailed, heteroscedastic $517 \quad t$-test); ns: non-significant $(P>0.1)$. 

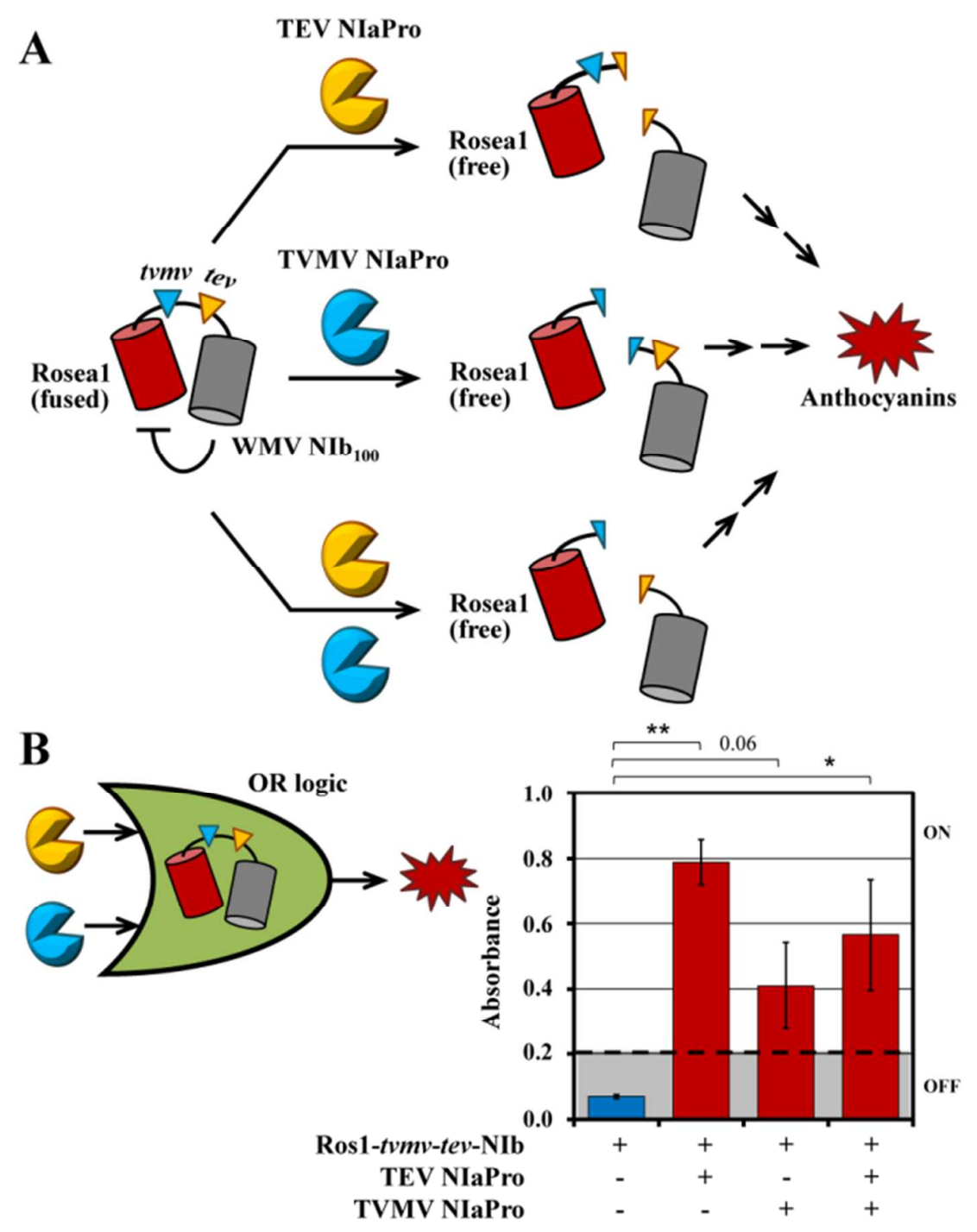

519

520

521

522

523

524

525

526

527

528

529

Figure 4. Synthetic circuit capable of performing Boolean OR computation in plants with visual output. Schematic representation of the reactions in which the reporter construct Ros1$t v m v$-tev-NIb $\mathrm{Nb}_{100}$ responds activating the accumulation of pigmented anthocyanins in the presence of TEV NIaPro or TVMV NIaPro (OR logic gate) (B) Graphic representation of the absorbance in $N$. benthamiana tissues infiltrated with $A$. tumefaciens to express the reporter construct Ros1-tvmv-tev-NIb ${ }_{100}$ alone (blue bars) or with TEV and TVMV NIaPros as indicated (red bars). Tissues from three independent plants were collected at 6 dpi and anthocyanins were quantified at $535 \mathrm{~nm}$. Error bars represent the standard error of the mean. ${ }^{*} P \leq 0.05$ and ${ }^{* *} P \leq 0.01$ (one-tailed, heteroscedastic $t$-test); 0.06 : marginally non-significant $(P=0.06)$. 

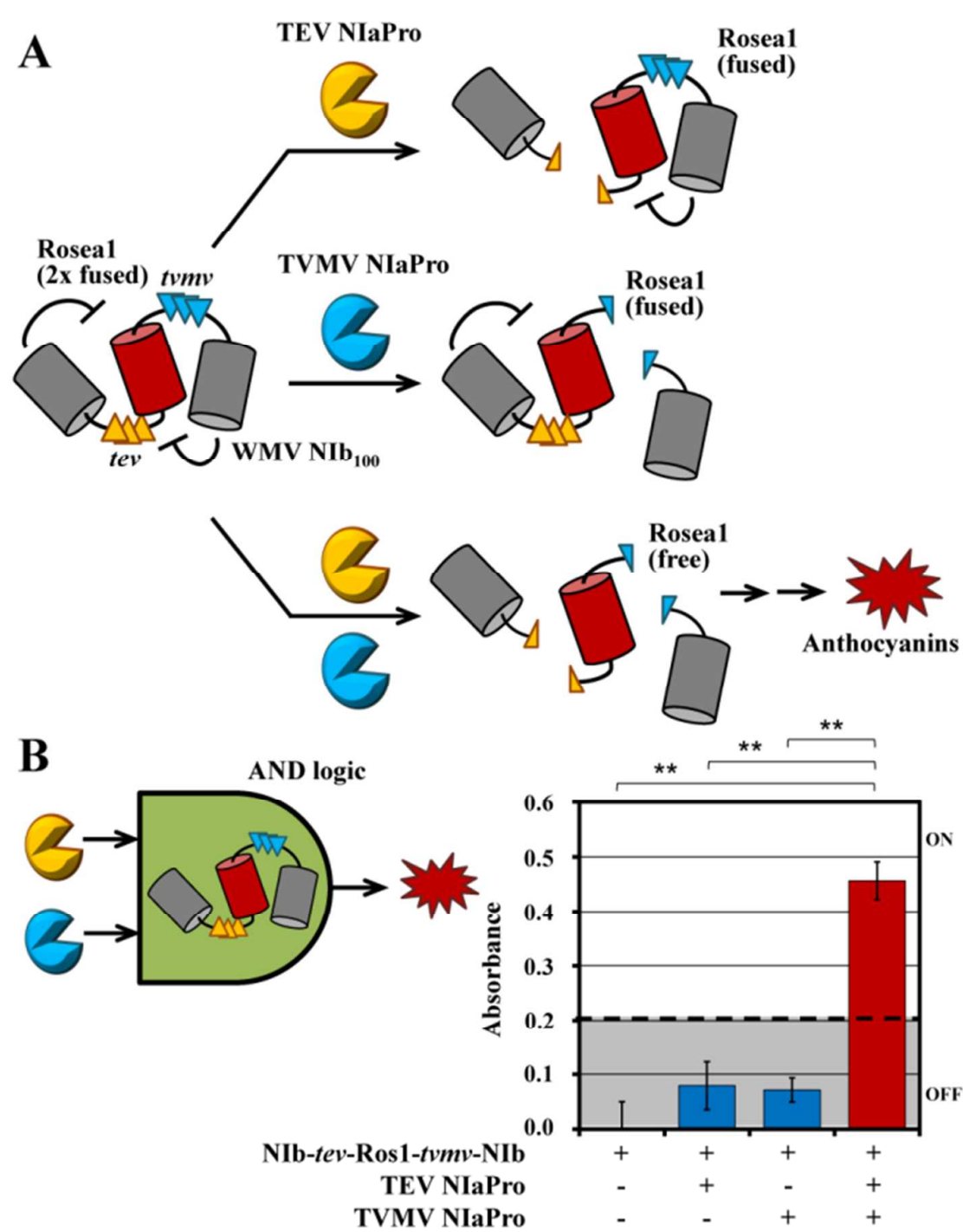

531

532

533

534

535

536

537

538

539

540

541

Figure 5. Synthetic circuit capable of performing Boolean AND computation in plants with visual output. (A) Schematic representation of the reactions in which the reporter construct $\mathrm{NIb}_{100}-3 \times t e v$-Ros1-3 $\times t v m v-\mathrm{NIb}_{100}$ responds activating the accumulation of pigmented anthocyanins in the presence of TEV and TVMV NIaPros (AND logic gate). (B) Graphic representation of the absorbance in $N$. benthamiana tissues infiltrated with A. tumefaciens to express the reporter constructs $\mathrm{NIb}_{100}-3 \times t e v$-Ros1-3 $\times t v m v-\mathrm{NIb}_{100}$ alone or with one NIaPro (blue bars) or with both TEV and TVMV NIaPros as indicated (red bars). Tissues from three independent plants were collected at 6 dpi and anthocyanins were quantified at $535 \mathrm{~nm}$. Error bars represent the standard error of the mean. ${ }^{* *} P \leq 0.01$ (one-tailed, heteroscedastic $t$-test). 
542 For Table of Contents Only

543

544

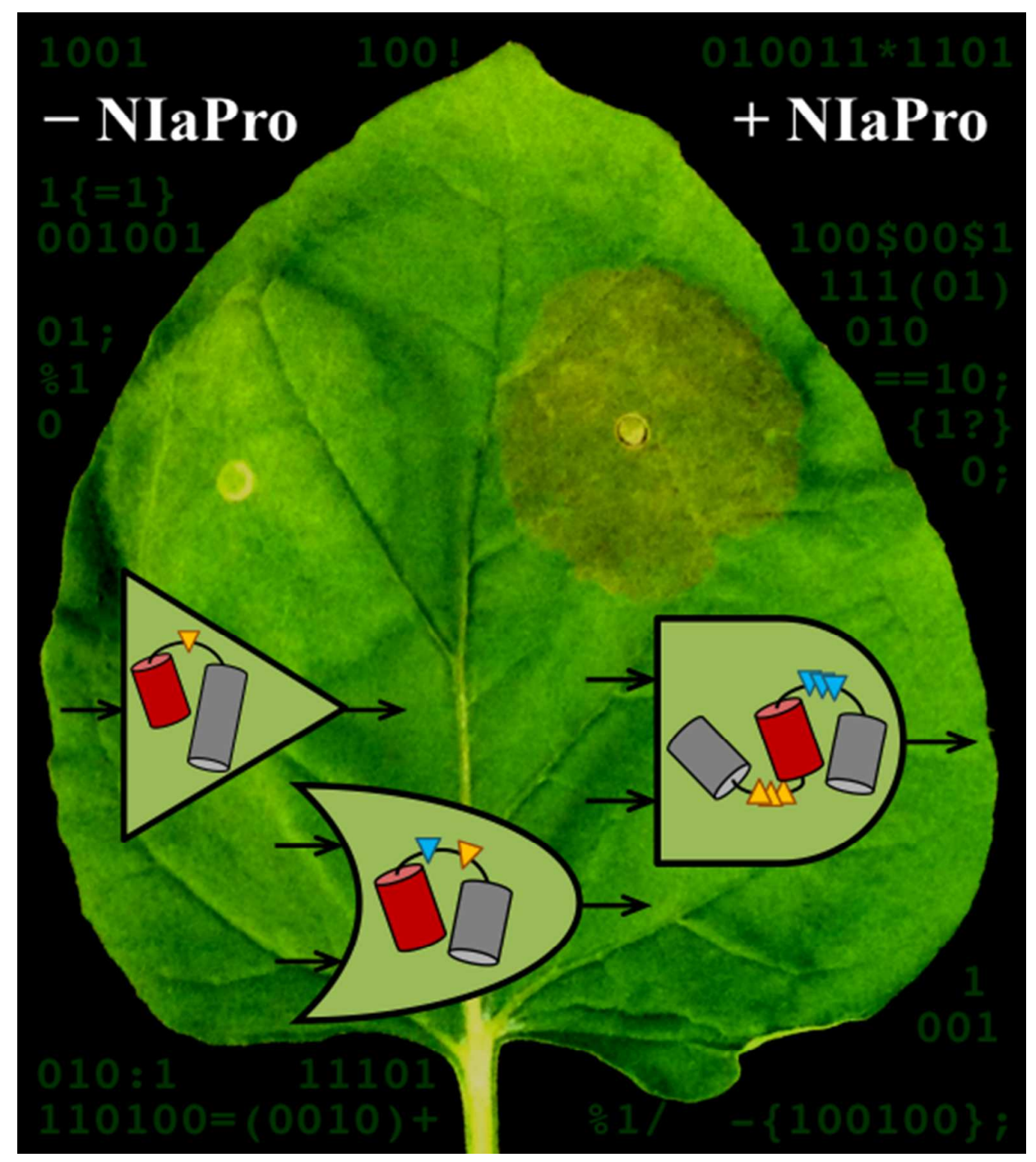

